\title{
microRNA221 is Involved in Human Placental Development by Targeting DDIT4
}

\author{
Bo Hua Guangtao Xu $\mathrm{H}^{\mathrm{a}, \mathrm{b}}$ Jie Tang ${ }^{\mathrm{a}}$ Xuebo Lib Ping Qian ${ }^{\mathrm{a}}$ \\ Ruilin Shen $^{\mathrm{a}}$ Long Xu $\mathrm{u}^{\mathrm{a}}$ Tesheng Gao ${ }^{\mathrm{a}}$ Nenghua Zhang \\ Jian $\mathrm{Hou}^{\mathrm{c}}$
}

aDepartment of Pathology and Molecular Medicine Center, Jiaxing Hospital of Traditional Chinese Medicine, Jiaxing University, Jiaxing, China, ${ }^{b}$ Key Laboratory of Evidence-Identifying in Universities of Shandong, Shandong University of Political Science and Law, Jinan, China, 'Department of Cardiac Surgery, The First Affiliated Hospital of Sun Yat-sen University, Guangzhou, China

\section{Key Words \\ miR221 • Placenta $•$ DDIT4 $•$ Target genes}

\begin{abstract}
Background/Aims: miR221 might have an important role in human embryo development. However, little is known about the function of miR221 in the human embryo. The aim of this study was to evaluate miR221 expression in human placental tissue, and to analyze the relationship between miR221 and target genes. Methods: The human placentas tissue samples were collected from healthy pregnant women who were willing to terminate their pregnancy. The total RNA isolation and microRNA reverse transcription quantification were performed by TaqMan microRNA assay and qRT-PCR. Results: The results showed that miR221 expression was significantly higher in 55 - to 71 -day placenta (mean value $=0.1049$ ) than that in 38 - to 54- day (the mean value $=0.0133)(p<0.001)$. miR221 targeting genes, such as PIK3R1, CDKN1B, CDKN1C, DDIT4, and FOS, were detected in human placenta tissue, but only DDIT4 was significantly decreased with development (mean value: 0.0101 for $38 \sim 54$ days, 0.0021 for $55 \sim 71$ days, $p<0.001$ ). Further analysis showed that only DDIT4 was negatively correlated with miR221 expression (DDIT4: $r=-0.396, p=0.033$; PI3KR: $r=0.322, p=0.089$; CDKN1B: $r=0.298$, $p=0.128$; CDKN1C: $r=0.198, p=0.304$; FOS: $r=0.171, p=0.347$ ). Conclusion: These findings indicate that miR221 might play an important role in human placental development by precisely regulating the DDIT4 expression.
\end{abstract}

B. Hu, G. Xu, and J. Tang contributed equally to this work. 


\section{Cellular Physiology Cell Physiol Biochem 2019;52:254-262 \\ \begin{tabular}{ll|l} 
and Biochemistry & $\begin{array}{l}\text { DOl: 10.33594/000000019 } \\
\text { Published online: } 28 \text { February } 2019\end{array}$ & $\begin{array}{l}\text { C 2019 The Author(s). Published by } \\
\text { Cell Physiol Biochem Press GmbH\&Co. KG }\end{array}$ \\
\cline { 2 - 3 }
\end{tabular} \\ Hu et al.: miR221 in Human Placental Development}

\section{Introduction}

MicroRNAs (miRNAs) are about 22-nucleotides, short, noncoding RNAs, which serve as an important regulator of protein levels by binding to 3'UTRs of target mRNAs and either inhibiting translation or inducing mRNA degradation [1-5]. miRNA is detected in all organisms and regulated stability or translation of $20 \sim 30 \%$ of all mRNAs in vertebrate [6-9]. Thus, miRNAs are important in different stages and processes of embryonic development, such as cell differentiation, proliferation, and organ formation $[10,11]$.

miR-221 is located at the X-chromosome and has 23 nucleotides. Previous reports suggest that miR-221 plays an important role in development and growth. It is expressed in neurons and/or cranial ganglia in forebrain and midbrain, as well as rhombomere in zebrafish embryo [12], suggesting its potential roles in brain development. Moreover, miR221 is observed to be down-regulated during differentiation of hematopoietic progenitor cells, which facilitates normal erythropoiesis and erythroleukemic cell growth via unblocking KIT protein production [13]. However, miR221 over-expression in the mouse liver could accelerate hepatocyte proliferation by leading to rapid S-phase entry of hepatocytes during liver regeneration $[14,15]$. Given the reported effect of miR221 on development and growth, it is proposed that miR221 might function in human embryo development. However, little is known about the function of miR221 in the human embryo.

Development of human placenta, which allows fetal-maternal exchanges during gestation, is critical for embryonic development. It is composed of a vascular network and stroma coming from the embryonic mesoderm, and of trophoblast cells that arise from the extra-embryonic tissue, and differentiate to achieve specialized functions [16-21]. In the current study, we examined the miR221 expression in human placental tissue and analyzed the relationship between miR221 and its targeting genes.

\section{Materials and Methods}

\section{Tissue collection}

Human placentas tissue samples $(n=29)$ were collected from the healthy pregnant women who were willing to terminate their pregnancy by vacuum aspiration at the PLA 458th hospital (Guangzhou, China), approved by local ethics committee of the hospital. Informed consent for the experimental use of the surgically removed samples was obtained at 5-10 weeks after their last menstrual period. Gestational age was determined based on the last menstrual period and by standard obstetric ultrasonography. At the time of the surgical procedure of abortion, the deciduas were separated from any products of conception under a dissecting microscope. First, the tissue samples were washed thoroughly with sterile normal saline to remove excess blood, mucous and fetal tissues. Then, fragments of decidua and deciduas with attached chorionic villi were transferred to a Petri dish with sterile normal saline which were examined under a dissecting microscope. The deciduas carefully dissected out from the branching chorionic villi were immediately kept in RNA-latter (Invitrogen, Carlsbad, CA) at $-80^{\circ} \mathrm{C}$ for qRT-PCR.

\section{Total RNA isolation, primers, and quantitative real-time PCR}

The samples were pulverized in liquid nitrogen and then thoroughly homogenized in $1 \mathrm{~mL}$ TRizol Reagent (Invitrogen, USA) per $100 \mathrm{mg}$ sample. The total RNA was extracted according to the manufacturer's instructions. The concentration of extracted RNA was determined by a spectrophotometer (BioPhotometer, Eppendorf, Germany). First-strand cDNA was reversely transcribed using $2 \mu \mathrm{g}$ of total RNA in a total volume of $20 \mu \mathrm{L}$ extracts according to the manufacturer's protocol of PrimerScript RT reagent Kit (Takara, Japan).

Each PCR reaction was performed with $2 \mu \mathrm{L}$ of the cDNA and $0.2 \mu \mathrm{mol} / \mathrm{L}$ of each primer in a LightCycler System with SsoAdvancedTM SYBR Green Supermix (Bio-Rad, USA). Briefly, the RT-PCR reactions were run at $95^{\circ} \mathrm{C}$ for $10 \mathrm{~min}$, followed by 40 cycles of $15 \mathrm{sec}$ at $95^{\circ} \mathrm{C}$ and $20 \mathrm{sec}$ at $60^{\circ} \mathrm{C}$ in the CFX96 realtime system (Bio-Rad). Each sample was assayed in triplicate and the primer sequences, and PCR conditions were listed in Table 1. Preliminary experiments were performed with each pair of primers. Formation of the expected single product was ascertained in each reaction by melt curve analysis (starting from $72^{\circ} \mathrm{C}$ to 
$\left.92.4^{\circ} \mathrm{C}\right)$. The gene expression level was determined using the delta $\mathrm{Ct}$ method $(\Delta \mathrm{Ct})$, a variation of the Livak method, where $\Delta \mathrm{Ct}=C t_{\text {reference gene }}-C t_{\text {target gene }}$.

\section{microRNA reverse transcription and quantification}

For the quantification of mature microRNAs, reverse transcription was performed using TaqMan MicroRNA Reverse Transcription Kit (Applied Biosystems, USA) with specific primer according to the manufacturer's protocol, and the products were stored at $-20^{\circ} \mathrm{C}$. The diluted total RNA $(2 \mathrm{ng} / \mu \mathrm{L}, 5 \mu \mathrm{L})$ was reverse-transcribed by a total volume reaction of $3 \mu \mathrm{L}$ RT primer and $7 \mu \mathrm{L}$ RT master in an RNase free PCR tube, and then was mixed gently. The reaction was performed in a thermal cycler (Bio-Rad) at $16^{\circ} \mathrm{C}$ for 30 $\min , 42^{\circ} \mathrm{C}$ for $30 \mathrm{~min}$, and $85^{\circ} \mathrm{C}$ for $5 \mathrm{~min}$. miRNA-221 expression was measured by qRT-PCR using TaqMan MicroRNA Assay Kit (Applied Biosystems) according to the manufacturer's instructions. In briefly, $1.33 \mu \mathrm{L}$ of cDNA was added to a final $20 \mu \mathrm{L}$ volume of qRT-PCR reaction, which contained $1 \mu \mathrm{L}$ TaqMan MicroRNA Assay, $10 \mu \mathrm{L}$ Universal PCR Master Mix, and 7.67 $\mu \mathrm{L}$ Nuclease-free water. The reaction was performed using a CFX96 real-time system (Bio-Rad) at $95^{\circ} \mathrm{C}$ for $10 \mathrm{~min}, 40$ cycles at $95^{\circ} \mathrm{C}$ for $15 \mathrm{sec}$ and $60^{\circ} \mathrm{C}$ for $60 \mathrm{sec}$. The target transcript levels were normalized against the internal control GAPDH's expression.

\section{Statistical analysis}

The statistical difference between two groups was calculated using the nonparametric Mann-Whitney $\mathrm{U}$ test. The nonparametric Spearman correlation test was used to analyze the correlation of qRT-PCR data. A $P<0.05$ was considered to be statistically significant.

\section{Results}

miR221 expression level during normal pregnancy

To analyze the role of miR221 in human placental tissue, qRT-PCR was performed to investigate the miR221 expression pattern in placental tissue at a gestational age of 39 to 71 days. The results showed that miR221 had a low-level expression in 38- to 54-day placenta tissue, and it began to increase at day 55. miR221 expression was higher in 55- to 71-day placenta tissue (mean value $=0.1049)$ than that in 38- to 54-day placenta tissue (mean value $=0.0133)(p<0.001)$ (Fig. 1$)$.

Table 1. The primer sequences used for qRT-PCR

\begin{tabular}{lc}
\hline Gene & Primers (5'-3') \\
\hline \multirow{2}{*}{ CDKN1B } & F: TAATTGGGGCTCCGGCTAACT \\
& R: TGCAGGTCGCTTCCTTATTCC \\
CDKN1C & F: GCGGCGATCAAGAAGCTGT \\
& R: GCTTGGCGAAGAAATCGGAGA \\
FOS & F: ATGGACCAGTGAAGCGATCAT \\
& R: GTTCCTCCAAACTAGAAGCAGC \\
DDIT4 & F: CTGGACAGCAGCAACAGTG \\
& R: ACACCCCATCCAGGTAAGC \\
PIK3R1 & F: AGCAACCTGGCAGAATTACGA \\
& R: AAACGTGCACATCGATCATTTC \\
GAPDH & F: CTGGGCTACACTGAGCACC \\
& R: AAGTGGTCGTTGAGGGCAATG \\
\hline
\end{tabular}

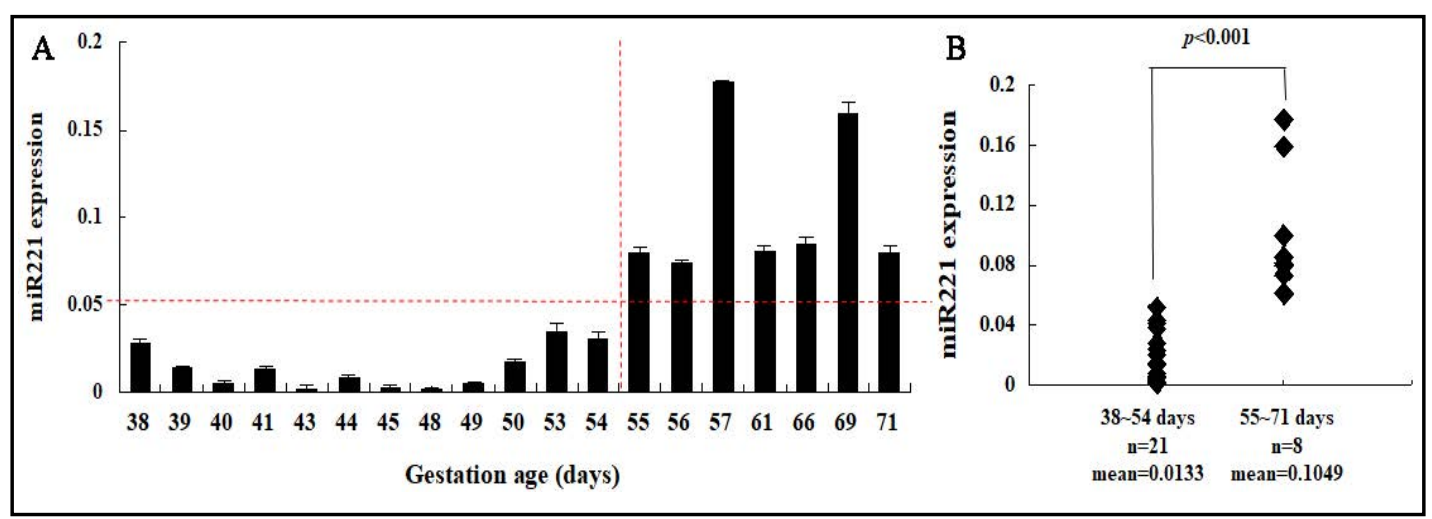

Fig. 1. MiR221 expression in human placental tissues. (A) miR221 expression in human placental tissues of different ages. The results were presented as the mean \pm SD of three experiments. (B) The different expression level of miR221 in 38- to 54- and 55- to 71-day placental tissue. The results were presented as dots for single samples. 
Table 2. The chosen target genes regulated by miR221 in this study

\begin{tabular}{|c|c|c|c|}
\hline Target gene & Interaction with miR221 & Function in embryo development & Refs. \\
\hline $\begin{array}{l}\text { CDKN1B } \\
\text { (p27) }\end{array}$ & $\begin{array}{l}\text { MiR-221 targets the CDK inhibitor p27 to enhance cell } \\
\text { growth in vitro. }\end{array}$ & Deficiency of CDKN1B results in overgrowth and neurodevelopmental delay. & {$[24,28]$} \\
\hline CDKN1C(p57) & $\begin{array}{l}\text { MiR-221 directly target the } 3 \text { 'untranslated regions of } \\
\text { p57 mRNAs to prevent quiescence that ensures cell } \\
\text { survival by coordinating competency for initiation of S- } \\
\text { phase. }\end{array}$ & Cdkn1c encodes the major regulator of embryonic growth. & {$[25,29]$} \\
\hline FOS & $\begin{array}{l}\text { Repression of c-Fos by miR-221 can inhibit the } \\
\text { megakaryocytic differentiation. }\end{array}$ & $\begin{array}{c}\text { Deficiency of FOS results in growth-retarding, developing osteopetrosis with } \\
\text { deficiencies in bone remodeling and tooth eruption, altering hematopoiesis, } \\
\text { suggesting its role as an essential molecule for the development of specific } \\
\text { cellular compartments. }\end{array}$ & {$[26,30]$} \\
\hline DDIT4 & $\begin{array}{l}\text { MiR-221 inhibits DDIT4 during hepatocarcinogenesis, } \\
\text { which resulting in dysregulation of the mTOR pathway. }\end{array}$ & $\begin{array}{l}\text { Knockdown of DDIT } 4 \text { in vitro and in vivo accelerates cell cycle exit by neuro- } \\
\text { progenitors and their differentiation into neurons. It also disrupts migration of } \\
\text { rat newborn neurons to the cortical plate and results in the ectopic localization } \\
\text { of mature neurons. On the other hand, DDIT4 overexpression delays neuronal } \\
\text { differentiation. }\end{array}$ & {$[23,31,32]$} \\
\hline PIK3R1 & $\begin{array}{l}\text { Decreased miR-221 was sufficient to cause a } \\
\text { corresponding increase in the expression of the } \\
\text { predicted target, PI3K, which may help to potentiate c- } \\
\text { Kit signaling in hematopoietic cells with advancing age. }\end{array}$ & $\begin{array}{l}\text { The heterozygous mice of endothelial cell-specific loss of class } 1 \mathrm{~A} \text { PI3K exhibited } \\
\text { localized vascular abnormalities, including vessel leakage and the inability to } \\
\text { maintain large vessels, which caused a deceleration of tumorigenesis. }\end{array}$ & {$[22,33]$} \\
\hline
\end{tabular}
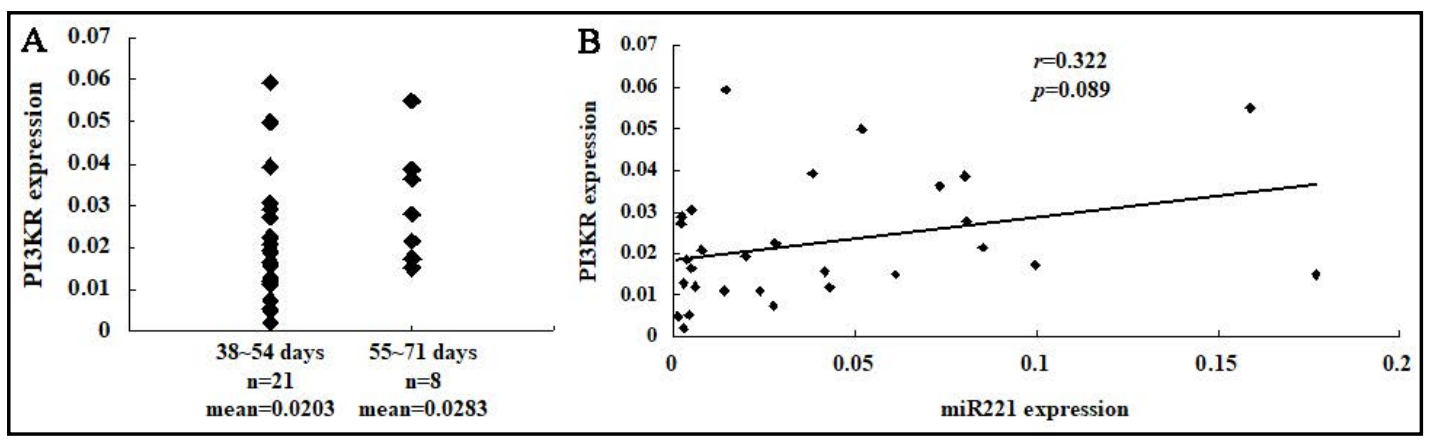

Fig. 2. PI3KR mRNA expression and its correlation with miR221 in human placental tissue. (A) The different expression levels of PI3KR mRNA in 38- to 54- and 55- to 71-day placental tissues. The results were presented as dots for single samples. (B) Correlation between PI3KR and miR221 level.

The mRNA levels of the reported target genes of miR122 and their correlation in human placenta tissue

It was reported that miR221 could target PI3K, DDIT4, CDKN1B, CDKN1C and FOS [2227], resulting in down-regulating these genes. Moreover, these genes have an important role in embryo development (Table 2).

To investigate the association between miR221 and these reported target genes in human placental development, the expression level of the reported target genes and their correlation with miR221 were analyzed. PI3KR was expressed during the placenta development, but no statistical difference was observed between 38- to 54-day (mean value $=0.0203$ ) and 55- to 71 -day (mean value $=0.0283$ ) samples $(p>0.05)$. Further correlation analysis showed that PI3K expression was not correlated with miR221 expression ( $r=0.322, p=0.089)$ (Fig. 2$)$. The expression of DDIT4 was decreased in older-age placenta tissues (mean value: 0.0101 for $38 \sim 54$ days, 0.0021 for 55 71 days, $p<0.001$ ), and was negatively correlated with miR221 expression ( $r=-0.396, p=0.033$ ) (Fig. 3). CDKN1B was detected in the placenta tissues (mean value: 0.0298 for $38 \sim 54$ days, 0.0378 for $55 \sim 71$ days, $p>0.05$ ), but no statistically significant association of CDKN1B with miR221 was observed ( $r=0.298, p=0.128$ ) (Fig. 4). CDKN1C was detected during the placenta development (mean value: 0.0582 for 38 54 days, 0.0847 for 55 71 days, $p>0.05$ ), with no statistically significant association between CDKN1C and miR221 expression ( $r=0.198, p=0.304)$ (Fig. 5). FOS was also discovered during the placenta development (mean value: 0.0298 for 38 54 days, 0.0303 for 55 71 days, $p>0.05$ ), and its expression was not significantly correlated with miR221 ( $r=0.171, p=0.347$ ) (Fig. 6). 


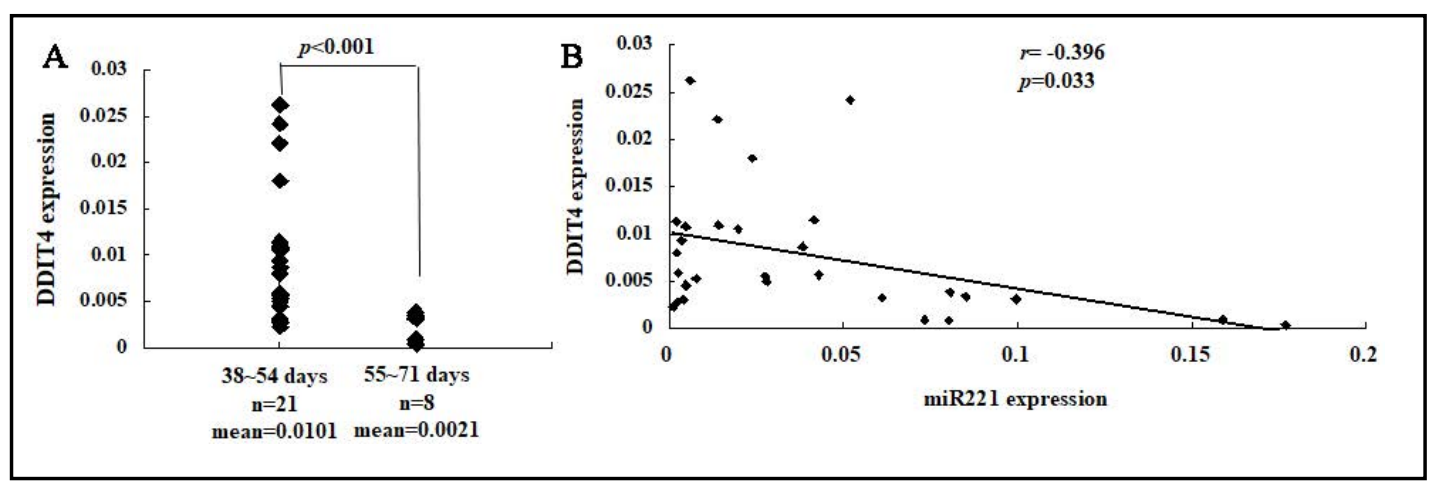

Fig. 3. DDIT4 mRNA expression and its correlation with miR221 in human placental tissues. (A) The different expression levels of DDIT4 mRNA in 38- to 54- and 55- to 71-day placental tissues. (B) The correlation between DDIT4 and miR221 level.

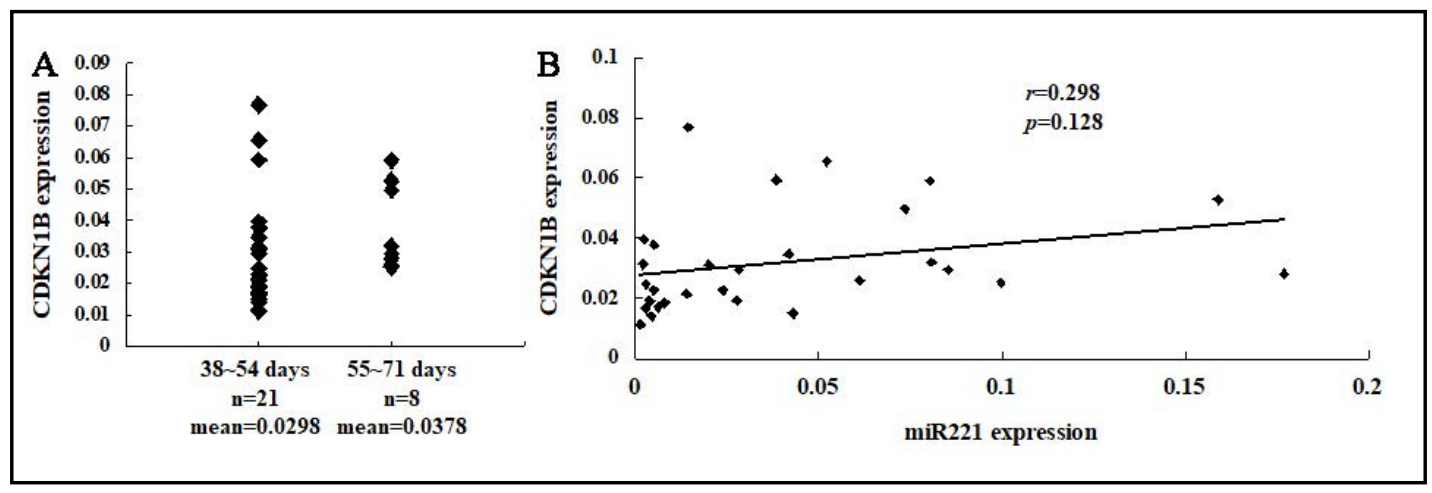

Fig. 4. CDKN1B mRNA expression and its correlation with miR221 in human placental tissues. (A) The different expression levesl of CDKN1B mRNA in 38- to 54- and 55- to 71-day placental tissues. (B) The correlation between CDKN1B and miR221 level.

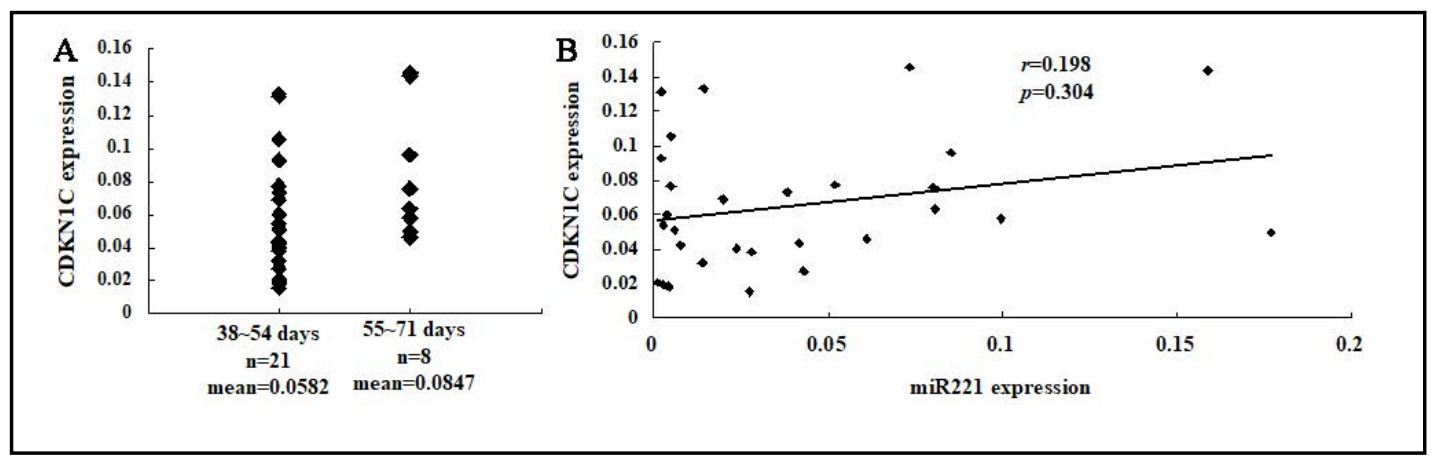

Fig. 5. CDKN1C mRNA expression and its correlation with miR221 in human placental tissues. (A) The different expression levels of CDKN1C mRNA in 38- to 54- and 55- to 71-day placental tissue. (B) The correlation between CDKN1C and miR221 level.

\section{Discussion}

So far, despite extensive studies carried out on miRNA, little is known on their role and even less on their targets in mammalian species [34-36]. In this study, we investigated the expression pattern of miR221 in human placenta and screened the DDIT4 as a potential target gene from a series of reported target genes. 


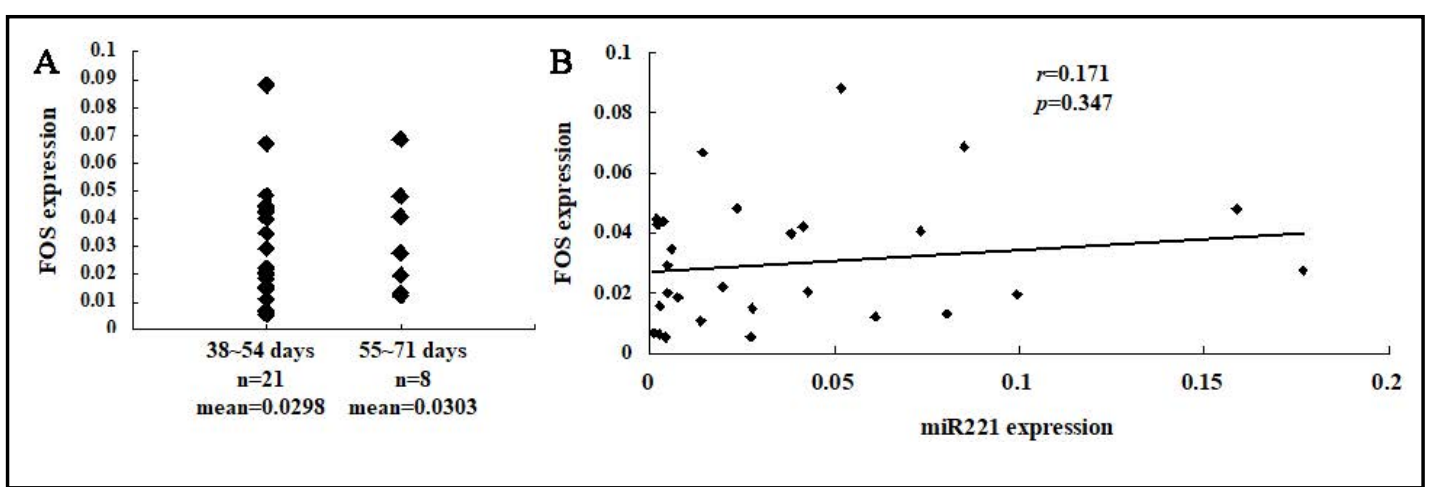

Fig. 6. FOS mRNA expression and its correlation with miR221 in human placental tissues. (A) The different expression levels of FOS mRNA in 38- to 54- and 55- to 71-day placental tissues. (B) The correlation between FOS and miR221 level.

MicroRNA is reported important in fetal growth restriction, pregnancy-related complications and preeclampsia, suggesting that it might play an important role in embryo development and could serve as a potential diagnostic marker for abnormal embryonic development [37-39]. miR221 is an important gene involved in development and growth [12-14], however, the function of miR221 in human embryo development remains unclear. Given that the development of the human placenta is critical for embryonic development [16-19], we focus on the role of miR221 in human placental tissues. Our study shows that miR221 was increased during human placental development. The expression of miR221 was low in 38- to 54-day placenta and began to increase at day 55. Further analysis showed that the level of miR221 expression in 55- to 71-day placenta was higher than in 38- to 54-day placenta (mean value: 0.0133 at 38 54 days, 0.1049 at 55 71 days, $p<0.001$ ), suggesting that the increased expression of miR221 may be age-dependent. miR221 was expressed at low level at week 5, week 6, and week 7 of gestational age. At week 5, the nervous system including the brain and spinal cord, heart, and gastrointestinal tract begins to develop. At week $6 \sim 7$ of gestational age, the arm and leg buds become visible, the brain develops into five areas and some cranial nerves are visible. The heart continues to develop and beat at a regular rhythm. Rudimentary blood moves through the main vessels [40]. Then, the expression of miR221 began to increase at the week 8, at which time the arms and legs grow longer, and foot and hand areas can be distinguished. The brain continues to form, and the lungs begin to form [40]. However, in the zebrafish embryo, miR-221 is expressed in neurons and/or cranial ganglia in forebrain and midbrain, as well as rhombomere, suggesting that miR221 has different functions in different species.

Accumulating data report the identification of aberrantly expressed miRNAs. Gene target prediction models and recent functional studies support the concept that miRNAs might impact the genesis and progression of diseases [41,42]. Thus, we focus on a series gene related to embryo development targeting by miR221, and examine the association between miR221 and some of target genes in human placental development. Our results revealed that enhanced miR221 expression was negatively correlated with DDIT4, but not CDKN1B, CDKN1C, FOS, and PIK3R1. DDIT4 is an important gene for embryo development. Knockdown of DDIT4 could accelerate cell cycle exit by neuro-progenitors and their differentiation into neurons, and disrupt the migration of rat newborn neurons to the cortical plate resulting in the ectopic localization of mature neurons. On the other hand, over-expression of DDIT4 could delay neuronal differentiation, suggesting its essential role in the temporal control of cortical development and in cortical patterning [32]. DDIT4 expression parallels that of p63 in some ectoderm-derived tissues [43]. In our study, DDIT4 was highly expressed in the early stage of placenta development (38 54 days), in which the nervous system is developing rapidly and begins to have specific functions [40]. These data suggest that DDIT4 has an essential role in nervous system development of the human embryo. Moreover, 
DDIT4 expression was significantly decreased in older-age placenta tissues (55 71 days), which might be regulated by miR221. DDIT4 could inhibit mTOR signaling by regulating the mTOR substrate phosphorylation [31]. Thus, decreasing expression of DDIT4 tissues might result in mTOR signaling enhancing in human placenta. mTOR signaling is essential for the development of both embryonic and extraembryonic tissue, and its inactivation leads to early post-implantation lethality $[44,45]$. Taken together, it is supposed that miR221 may play important role in placental development by precisely controlling the expression timing of DDIT4, in which the mTOR signaling pathway was also regulated.

\section{Conclusion}

In summary, we have shown that miR221 is up-regulated during human placental development. DDIT4, the reported target gene of miR221, was down-regulated in human placenta tissue. miR221 expression is negatively correlated with DDIT4 expression. miR221 may play an important role in human placental development by precisely regulating the DDIT4 expression, which serves as a switch of the mTOR signaling pathway.

\section{Acknowledgements}

The authors greatly appreciate the editors and the anonymous peer reviewers for their critical reading and insightful comments, which have improved our manuscript substantially. This study was supported by the Sci-Tech Planning Project of Zhejiang Province (LGF19H050003, 2015C33295, and 2015C37130), the Opening Project of Key Laboratory of Evidence-Identifying in Universities of Shandong, Shandong University of Political Science and Law (2018KFKT2), and the Sci-Tech Planning Project of Jiaxing (2017AY33056 and 2017BY18042). We apologize to the many researchers whose work could not be cited due to space limitations.

\section{Disclosure Statement}

The authors have declared that no conflicts of interest exist.

\section{References}

- 1 He L, Hannon GJ: MicroRNAs: small RNAs with a big role in gene regulation. Nat Rev Genet 2004;5:522-531.

- 2 Pillai RS: MicroRNA function: multiple mechanisms for a tiny RNA? RNA 2005;11:1753-1761.

- 3 Valencia-Sanchez MA, Liu J, Hannon GJ, Parker R: Control of translation and mRNA degradation by miRNAs and siRNAs. Genes Dev 2006;20:515-524.

4 Zheng Y, Zhou J, Li X, Xu G, Jin M, Shen R, Su R, Zhan S, Ding B, Jia M, Cui Y, Yu X: miR-382 Promotes Differentiation of Rat Liver Progenitor Cell WB-F344 by Targeting Ezh2. Cell Physiol Biochem 2018;48:2389-2398.

5 Jafari Ghods F, Topal Sarikaya A, Arda N, Hamuryudan V: MiRNA and mRNA Profiling in Systemic Lupus Reveals a Novel Set of Cytokine - Related miRNAs and their Target Genes in Cases With and Without Renal Involvement. Kidney Blood Press Res 2017;42:1322-1337.

6 Bentwich I, Avniel A, Karov Y, Aharonov R, Gilad S, Barad O, Barzilai A, Einat P, Einav U, Meiri E, Sharon E, Spector Y, Bentwich Z: Identification of hundreds of conserved and nonconserved human microRNAs. Nat Genet 2005;37:766-770.

7 Berezikov E, Plasterk RH: Camels and zebrafish, viruses and cancer: a microRNA update. Hum Mol Genet 2005;14:R183-R190. 


\section{Cellular Physiology Cell Physiol Biochem 2019;52:254-262

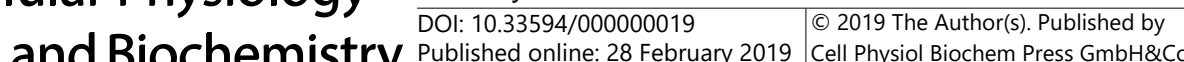 and Biochemistry Published online: 28 February 2019 Cell Physiol Biochem Press GmbH\&Co. KG \\ Hu et al.: miR221 in Human Placental Development}

8 Legendre M, Lambert A, Gautheret D: Profile-based detection of microRNA precursors in animal genomes. Bioinformatics 2005;21:841-845.

9 Xie X, Lu J, Kulbokas EJ, Golub TR, Mootha V, Lindblad-Toh K, Lander ES, Kellis M: Systematic discovery of regulatory motifs in human promoters and 3' UTRs by comparison of several mammals. Nature 2005;434:338-345.

- 10 Stefani G, Slack FJ: Small non-coding RNAs in animal development. Nat Rev Mol Cell Biol 2008;9:219-230.

- 11 Zou XY, Yu Y, Lin S, Zhong L, Sun J, Zhang G, Zhu Y: Comprehensive miRNA Analysis of Human Umbilical Cord-Derived Mesenchymal Stromal Cells and Extracellular Vesicles. Kidney Blood Press Res 2018;43:152161.

12 Wienholds E, Kloosterman WP, Miska E, Alvarez-Saavedra E, Berezikov E, de Bruijn E, Horvitz HR, Kauppinen S, Plasterk RH: MicroRNA expression in zebrafish embryonic development. Science 2005;309:310-311.

13 Felli N, Fontana L, Pelosi E, Botta R, Bonci D, Facchiano F, Liuzzi F, Lulli V, Morsilli O, Santoro S, Valtieri M, Calin GA, Liu CG, Sorrentino A, Croce CM, Peschle C: MicroRNAs 221 and 222 inhibit normal erythropoiesis and erythroleukemic cell growth via kit receptor down-modulation. Proc Natl Acad Sci U S A 2005;102:18081-18086.

14 Yuan Q, Loya K, Rani B, Mobus S, Balakrishnan A, Lamle J, Cathomen T, Vogel A, Manns MP, Ott M, Cantz T, Sharma AD: MicroRNA-221 overexpression accelerates hepatocyte proliferation during liver regeneration. Hepatology 2013;57:299-310.

- 15 Jia QW, Chen ZH, Ding XQ Liu JY, Ge PC, An FH, Li LH, Wang LS, Ma WZ, Yang ZJ, Jia EZ: Predictive Effects of Circulating miR-221, miR-130a and miR-155 for Coronary Heart Disease: A Multi-Ethnic Study in China. Cell Physiol Biochem 2017;42:808-823.

- 16 Coan PM, Ferguson-Smith AC, Burton GJ: Ultrastructural changes in the interhaemal membrane and junctional zone of the murine chorioallantoic placenta across gestation. J Anat 2005;207:783-796.

17 Cross JC: Genetic insights into trophoblast differentiation and placental morphogenesis. Semin Cell Dev Biol 2000;11:105-113.

18 Rossant J, Cross JC: Placental development: lessons from mouse mutants. Nat Rev Genet 2001;2:538-548.

19 Simmons DG, Cross JC: Determinants of trophoblast lineage and cell subtype specification in the mouse placenta. Dev Biol 2005;284:12-24.

20 Hu B, Wu T, Zhao Y, Xu G, Shen R, Chen G: Physiological Signatures of Dual Embryonic Origins in Mouse Skull Vault. Cell Physiol Biochem 2017;43:2525-2534.

21 Wu T, Chen G, Tian F, Liu HX: Contribution of cranial neural crest cells to mouse skull development. Int J Dev Biol 2017;61:495-503.

22 Noren Hooten N, Abdelmohsen K, Gorospe M, Ejiogu N, Zonderman AB, Evans MK: microRNA expression patterns reveal differential expression of target genes with age. PLoS One 2010;5:e10724.

23 Pineau P, Volinia S, McJunkin K, Marchio A, Battiston C, Terris B, Mazzaferro V, Lowe SW, Croce CM, Dejean A: miR-221 overexpression contributes to liver tumorigenesis. Proc Natl Acad Sci U S A 2010;107:264-269.

24 Felicetti F, Errico MC, Bottero L, Segnalini P, Stoppacciaro A, Biffoni M, Felli N, Mattia G, Petrini M, Colombo MP, Peschle C, Care A: The promyelocytic leukemia zinc finger-microRNA-221/-222 pathway controls melanoma progression through multiple oncogenic mechanisms. Cancer Res 2008;68:2745-2754.

25 Medina R, Zaidi SK, Liu CG, Stein JL, van Wijnen AJ, Croce CM, Stein GS: MicroRNAs 221 and 222 bypass quiescence and compromise cell survival. Cancer Res 2008;68:2773-2780.

26 Ichimura A, Ruike Y, Terasawa K, Shimizu K, Tsujimoto G: MicroRNA-34a inhibits cell proliferation by repressing mitogen-activated protein kinase kinase 1 during megakaryocytic differentiation of K562 cells. Mol Pharmacol 2010;77:1016-1024.

27 Yang W, Yang Y, Xia L, Yang Y, Wang F, Song M, Chen X, Liu J, Song Y, Zhao Y, Yang C: miR-221 Promotes Capan-2 Pancreatic Ductal Adenocarcinoma Cells Proliferation by Targeting PTEN-Akt. Cell Physiol Biochem 2016;38:2366-2374.

28 Grey W, Izatt L, Sahraoui W, Ng YM, Ogilvie C, Hulse A, Tse E, Holic R, Yu V: Deficiency of the cyclindependent kinase inhibitor, CDKN1B, results in overgrowth and neurodevelopmental delay. Hum Mutat 2013;34:864-868.

29 Andrews SC, Wood MD, Tunster SJ, Barton SC, Surani MA, John RM: Cdkn1c (p57Kip2) is the major regulator of embryonic growth within its imprinted domain on mouse distal chromosome 7. BMC Dev Biol $2007 ; 7: 53$. 


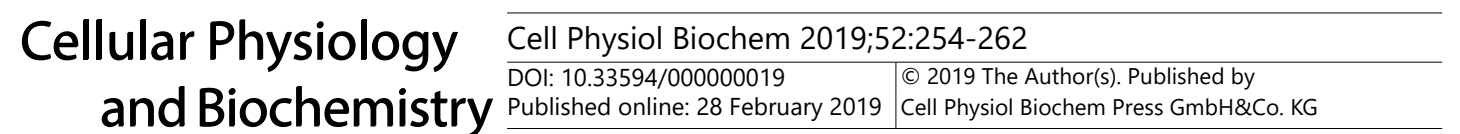 \\ Hu et al.: miR221 in Human Placental Development}

30 Wang ZQ, Ovitt C, Grigoriadis AE, Mohle-Steinlein U, Ruther U, Wagner EF: Bone and haematopoietic defects in mice lacking c-fos. Nature 1992;360:741-745.

31 Sofer A, Lei K, Johannessen CM, Ellisen LW: Regulation of mTOR and cell growth in response to energy stress by REDD1. Mol Cell Biol 2005;25:5834-5845.

- 32 Malagelada C, Lopez-Toledano MA, Willett RT, Jin ZH, Shelanski ML, Greene LA: RTP801/REDD1 regulates the timing of cortical neurogenesis and neuron migration. J Neurosci 2011;31:3186-3196.

33 Yuan TL, Choi HS, Matsui A, Benes C, Lifshits E, Luo J, Frangioni JV, Cantley LC: Class 1A PI3K regulates vessel integrity during development and tumorigenesis. Proc Natl Acad Sci U S A 2008;105:9739-9744.

34 Chen CZ, Li L, Lodish HF, Bartel DP: MicroRNAs modulate hematopoietic lineage differentiation. Science 2004;303:83-86.

35 Poy MN, Eliasson L, Krutzfeldt J, Kuwajima S, Ma X, Macdonald PE, Pfeffer S, Tuschl T, Rajewsky N, Rorsman P, Stoffel M: A pancreatic islet-specific microRNA regulates insulin secretion. Nature 2004;432:226-230.

36 Su Q Li L, Zhao J, Sun Y, Yang H: miRNA Expression Profile of the Myocardial Tissue of Pigs with Coronary Microembolization. Cell Physiol Biochem 2017;43:1012-1024.

37 Chiofalo B, Lagana AS, Vaiarelli A, La Rosa VL, Rossetti D, Palmara V, Valenti G, Rapisarda AMC, Granese R, Sapia F, Triolo O, Vitale SG: Do miRNAs Play a Role in Fetal Growth Restriction? A Fresh Look to a Busy Corner. Biomed Res Int 2017;2017:6073167.

38 Lycoudi A, Mavreli D, Mavrou A, Papantoniou N, Kolialexi A: miRNAs in pregnancy-related complications. Expert Rev Mol Diagn 2015;15:999-1010.

- 39 Lagana AS, Vitale SG, Sapia F, Valenti G, Corrado F, Padula F, Rapisarda AMC, D’Anna R: miRNA expression for early diagnosis of preeclampsia onset: hope or hype? J Matern Fetal Neonatal Med 2018;31:817-821.

40 Cunningham F, Leveno KJ, Bloom S, Hauth JC, Rouse DJ, Spong CY: Williams Obstetrics, Fetal Growth and Development (Chapter 2.4), ed 23. New York, McGraw-Hill Professional Publishing, 2010.

41 Cosar E, Mamillapalli R, Ersoy GS, Cho S, Seifer B, Taylor HS: Serum microRNAs as diagnostic markers of endometriosis: a comprehensive array-based analysis. Fertil Steril 2016;106:402-409.

42 Karmon AE, Cardozo ER, Rueda BR, Styer AK: MicroRNAs in the development and pathobiology of uterine leiomyomata: does evidence support future strategies for clinical intervention? Hum Reprod Update 2014;20:670-687.

43 Ellisen LW, Ramsayer KD, Johannessen CM, Yang A, Beppu H, Minda K, Oliner JD, McKeon F, Haber DA: REDD1, a developmentally regulated transcriptional target of p63 and p53, links p63 to regulation of reactive oxygen species. Mol Cell 2002;10:995-1005.

44 Gangloff YG, Mueller M, Dann SG, Svoboda P, Sticker M, Spetz JF, Um SH, Brown EJ, Cereghini S, Thomas G, Kozma SC: Disruption of the mouse mTOR gene leads to early postimplantation lethality and prohibits embryonic stem cell development. Mol Cell Biol 2004;24:9508-9516.

- 45 Shiota C, Woo JT, Lindner J, Shelton KD, Magnuson MA: Multiallelic disruption of the rictor gene in mice reveals that mTOR complex 2 is essential for fetal growth and viability. Dev Cell 2006;11:583-589. 